\title{
Linkage and association studies between the proopiomelanocortin (POMC) gene and obesity in caucasian families
}

\author{
J. Delplanque ${ }^{1}$, M. Barat-Houari ${ }^{1}$, C. Dina ${ }^{1}$, P. Gallina ${ }^{1}$, K. Clément ${ }^{2}$, B. Guy-Grand ${ }^{2}$, F. Vasseur ${ }^{1}$, P. Boutin ${ }^{1}$, \\ P. Froguel ${ }^{1}$ \\ ${ }^{1}$ Institute of Biology-CNRS 8090, Pasteur Institute of Lille, CHRU of Lille, Lille, France \\ ${ }^{2}$ Nutrition Department, Hôtel-Dieu, Paris, France
}

\section{Abstract}

Aims/hypothesis. The region 2p21-23, containing the proopiomelanocortin gene $(P O M C)$, was reported to be linked to leptin concentrations in MexicanAmerican, French and African-American cohorts. A polyhormone peptide, $P O M C$ is expressed in brain, gut, placenta and pancreas. The $P O M C$ mutations are responsible for rare cases of early-onset obesity. Thus we examined the contribution of the POMC locus to obesity in French families.

Methods. Single and multipoint linkage studies were done between obesity, obesity associated-phenotypes (leptin values and $\mathrm{z}$-score of the body mass index) and three newly mapped markers surrounding $P O M C$ in 264 affected sib-pairs from French obese families. Mutation screening of the exons and intron/ exon junctions of the POMC gene was realised by direct sequencing. Association studies were done in 379 unrelated obese patients and 370 non-obese non-diabetic subjects.
Results. Linkage analysis confirmed the trend towards linkage between polymorphic markers around $P O M C$ and variations of leptin concentrations and $\mathrm{z}$-score (maximum lod score at D2S2337 $=2.03$ ). $\mathrm{Mu}$ tation screening of the POMC gene in the French Caucasian cohort identified two previously reported polymorphisms. None of these variants was associated with obesity, diabetes or serum leptin and lipid concentrations.

Conclusion/interpretation. Our results indicate that mutations in the POMC gene do not contribute to the variance of obesity associated phenotypes, at least in French Caucasians. Given the replicated evidence of linkage between leptin values and the chromosome 2p21-23 region in different populations, it is likely that functional variant(s) in the $P O M C$ regulating sequences or in an unknown gene in this region explains this linkage. [Diabetologia (2000) 43: 1554-1557]

Keywords POMC, Proopiomelanocortin, obesity, leptin.
In a collection of French obese families a genomewide scan in affected sib-pairs showed evidence for linkage of serum leptin concentrations with markers on chromosome $2 \mathrm{p}$ [log of the odds score (lod score $)=2.68$ ] [1]. This region contains the proopiomelanocortin gene (POMC) involved in the leptin/

Received: 12 July 2000 and in revised form: 18 August 2000

Corresponding author: Professor P. Froguel, CNRS 8090, Institut Pasteur de Lille, 1 rue. Calmette, F-59019 Lille Cedex, France

Abbreviations: POMC, Proopiomelanocortin; UTR, untranslated; lod score, log of the odds score. melanocortin pathway. It is expressed in human brain, gut, placenta and pancreas [2]. Polymorphisms in the $P O M C$ gene are associated with leptin concentrations [3] and mutations in the POMC gene were identified in children presenting early-onset obesity with a recessive mode of inheritance, abnormal hair colour and adrenal deficiency [4]. To examine the contribution of the $P O M C$ gene in obesity, we did linkage analyses using polymorphic markers around the $P O M C$ gene. In addition, we screened this gene for mutations in French obese patients and did association studies with identified genetic variants of the $P O M C$ gene. 
Table 1. Linkage results from 264 sib-pairs

\begin{tabular}{|c|c|c|c|c|c|}
\hline Marker & $\begin{array}{l}\text { OB } \\
p \text { value }\end{array}$ & $\begin{array}{l}\text { Leptin } \\
p \text { value }\end{array}$ & $\begin{array}{l}\text { Leptin } \\
\text { lod score }\end{array}$ & $\begin{array}{l}\text { z-score } \\
p \text { value }\end{array}$ & $\begin{array}{l}\text { z-score } \\
\text { lod score }\end{array}$ \\
\hline$\overline{\mathrm{D} 2 S 2221}$ & 0.08160 & 0.053 & 1.6132 & 0.0902 & 0.8578 \\
\hline D2S171 & 0.33380 & 0.051 & 1.6311 & 0.0580 & 1.2245 \\
\hline
\end{tabular}

Linkage results at markers surrounding the POMC gene. Column OB is the $p$ value of the linkage calculated with the obese status $\left(\mathrm{BMI}>27 \mathrm{~kg} / \mathrm{m}^{2}\right)$

\section{Subjects and methods}

Linkage studies. Families and patients with obesity used for the $P O M C$ gene screening and for association studies are part of a collection of French patients recruited from the Department of Nutrition at the Hôtel-Dieu Hospital in Paris (46\%) and by a multimedia campaign at the Pasteur Institute of Lille $(54 \%)$ in France. Each patient gave informed consent. We selected 158 nuclear families (514 people) with at least one morbidly obese proband $\left(\mathrm{BMI}>40 \mathrm{~kg} / \mathrm{m}^{2}\right)$ and one or several subjects with a BMI greater than $27 \mathrm{~kg} / \mathrm{m}^{2}$ in the sibship (264 sib-pairs). Genotyping was done with microsatellite markers around the $P O M C$ locus as described previously [1]. The human $P O M C$ gene was mapped with Genebridge 3 Radiation Hybrid Panel (Research Genetics, Huntsville, Ala., USA). Results were submitted to the SHGC RHSERVER (1999 Stanford Human Genome Center. http://www-shgc.stanford.edu/cgi-bin/smap).

Linkage analyses. We used the regressive approach proposed by Haseman and Elston, implemented in the Sage package [5]. This method regresses a function of the sibs' phenotypes with the proportion of alleles shared identical by descent between the two sibs of a pair.

Mutation screening of POMC. Exons and intron/exon junctions of the $P O M C$ gene were screened by direct sequencing in 11 lean (mean age $48 \pm 11$ years, BMI $26 \pm 2.4 \mathrm{~kg} / \mathrm{m}^{2}$, sex ratio five men:six women) and 48 obese subjects (mean age $54 \pm 10$ years, BMI $41 \pm 7 \mathrm{~kg} / \mathrm{m}^{2}, 19$ men:29 women) selected among the families contributing to the linkage to leptin concentrations at the D2S165 locus.

Association studies. Association studies were done in 192 unrelated obese patients (mean age $48.4 \pm 12$ years, BMI $33.3 \pm 2.4$ $\mathrm{kg} / \mathrm{m}^{2}, 71$ men:121 women) and in 189 non-obese non-diabetic subjects (mean age $60.7 \pm 11.2$ years, BMI $22.5 \pm 2.2 \mathrm{~kg} / \mathrm{m}^{2}$, 75 men:114 women). The 9 bp insertion/deletion variant at codon 94 was tested by PCR amplification, as described previously [6]. The 3' untranslated (UTR) nt $7566 \mathrm{C}>\mathrm{T}$ variant was genotyped by PCR-RFLP, Mbo II endonuclease (New England Biolabs, Beverly, Mass., USA) restricting the variant $\mathrm{T}$ allele. For the 3'UTR nt $7566 \mathrm{C}>\mathrm{T}$ variant, analyses were extended to a set of 379 obese (mean age $48.0 \pm 13.9$ years, BMI $33.9 \pm 3.4 \mathrm{~kg} / \mathrm{m}^{2}, 165 \mathrm{men}: 214$ women) and 370 control subjects (mean age $56.8 \pm 13.5$ years, BMI $22.8 \pm 2.4 \mathrm{~kg} / \mathrm{m}^{2}$, 146 men:224 women). Genotype frequencies were compared using the chi-squared ratios calculated under dominant, codominant and recessive models. Threshold $p$ values for significance were 0.001 for linkage and 0.05 for association studies.

\section{Results}

Linkage studies. By radiation hybrid mapping, the $P O M C$ gene was localised at $6 \mathrm{cRs}$ from the D2S171 microsatellite anchor marker shgc-398 (lod score 11.47) and 7cRs from the shgc-31106 marker (lod score 10.68). In addition we identified the POMC gene and the D2S171 marker in the same BAC clone (data not shown). Analyses with the dichotomous "Obese" status showed no evidence of linkage with the D2S171 marker and the D2S2221, D2S2337 markers close to D2S171 (Table 1). In contrast, quantitative trait analyses showed some evidence of linkage with serum leptin concentrations and z-scores (that is the standard deviation of the BMI corrected for age and sex). The multipoint lod scores were 2.00 and 1.30 , respectively. Moreover, single point results supported these data (Table 1). The best evidence for linkage was at D2S2337 (lod score of 2.03 for leptin concentrations and of 1.68 for $\mathrm{z}$-scores).

POMC screening for mutations. We detected two previously reported polymorphisms [3, 7] in the 59 samples screened: a 9 bp insertion/deletion in the coding region at codon 94 and a $C>T$ variant at position 7566 in the 3'UTR. Of the subjects five were heterozygotes for the 9 bp insertion/deletion in exon 3 and 17 subjects were heterozygotes for the $\mathrm{C}>\mathrm{T}$ variant in the 3'UTR. No additional DNA variations were identified.

Association studies. Frequencies of the codon 94 insertion/deletion polymorphism were 0.05 in the obese group and 0.06 in the control group, respectively. Frequencies of the $\mathrm{C}>\mathrm{T}$ variant were 0.17 and 0.18 in the obese and control groups, respectively. None of the polymorphisms showed statistically significant deviation from the Hardy-Weinberg equilibrium and there was no significant linkage disequilibrium between the two polymorphisms. There was no association of the POMC polymorphisms with obesity or with the diabetes status (data not shown).

Analyses of variance between both $P O M C$ variants and obesity-related phenotypes showed no association in our obese cohort in both sexes (Table 2). Leptin concentrations were not available in the control group. After the initial genotyping of 192 obese and 189 control subjects, a trend towards an association between the $\mathrm{C}>\mathrm{T}$ polymorphism and the BMI 
Table 2. Association studies

\begin{tabular}{|c|c|c|c|c|c|c|c|}
\hline & & \multicolumn{3}{|l|}{ Ins $9 \mathrm{bp}$} & \multicolumn{3}{|l|}{$\mathrm{C}>\mathrm{T}$ 3'UTR } \\
\hline & & wild & with ins $9 \mathrm{bp}$ & & wild & with variant & \\
\hline \multirow[t]{2}{*}{$\begin{array}{l}\text { Leptin } \\
\text { concentration }\end{array}$} & Obese women & $\begin{array}{l}41.68 \pm 21.55 \\
n=109\end{array}$ & $\begin{array}{l}40.14 \pm 18.32 \\
n=12\end{array}$ & $p>0.05$ & $\begin{array}{l}42.31 \pm 21.25 \\
n=142\end{array}$ & $\begin{array}{l}39.50 \pm 21.15 \\
n=72\end{array}$ & $p>0.05$ \\
\hline & Obese men & $\begin{array}{l}11.09 \pm 5.12 \\
n=64\end{array}$ & $\begin{array}{l}10.06 \pm 5.52 \\
n=7\end{array}$ & $p>0.05$ & $\begin{array}{l}10.66 \pm 4.93 \\
n=112\end{array}$ & $\begin{array}{l}12.44 \pm 5.92 \\
n=53\end{array}$ & $p>0.05$ \\
\hline \multirow[t]{2}{*}{$\begin{array}{l}\mathrm{BMI} \\
\mathrm{Kg} / \mathrm{m}^{2}\end{array}$} & Obese & $\begin{array}{l}33.19 \pm 2.30 \\
n=173\end{array}$ & $\begin{array}{l}34.30 \pm 2.84 \\
n=19\end{array}$ & $p>0.05$ & $\begin{array}{l}33.81 \pm 3.16 \\
n=254\end{array}$ & $\begin{array}{l}34.22 \pm 3.77 \\
n=125\end{array}$ & $p>0.05$ \\
\hline & Control & $\begin{array}{l}22.49 \pm 2.19 \\
n=166\end{array}$ & $\begin{array}{l}22.90 \pm 2.25 \\
n=23\end{array}$ & $p>0.05$ & $\begin{array}{l}22.99 \pm 2.39 \\
n=245\end{array}$ & $\begin{array}{l}22.75 \pm 2.36 \\
n=125\end{array}$ & $p>0.05$ \\
\hline
\end{tabular}

Among the 379 obese patients only 11 (5 men, 6 women) were TT for the C > T 3'UTR. Likewise among the 370 control subjects 10 were TT (4 men, 6 women)

in obese women was observed under a dominant model $\left(34.02 \pm 2.36\right.$ vs $\left.33.24 \pm 2.54 \mathrm{~kg} / \mathrm{m}^{2}, p=0.07\right)$. Thus genotyping was extended to a total set of 379 obese and 370 control subjects. In this larger cohort, no association with BMI was found $(34.4 \pm 3.08$ vs $\left.34.5 \pm 3.85 \mathrm{~kg} / \mathrm{m}^{2}, p>0.05\right)$. None of the polymorphisms studied had a statistically significant association with fasting glycaemia, insulinaemia or with serum lipid concentrations.

\section{Discussion}

As a region on chromosome $2 \mathrm{p}$ containing the $P O M C$ gene showed evidence of linkage with serum leptin concentrations in three cohorts of different ethnical origin $[1,8,9]$, additional linkage analyses were done. New markers surrounding the POMC gene locus were mapped by radiation hybrids. Although the results did not present evidence of a strong linkage, there was a trend towards a linkage between D2S2221, D2S171, D2S2337 and variation of leptin concentrations and z-scores. Informativeness in this region calculated by GeneHunter was satisfactorarily high (0.81). No linkage was detected with the dichotomous obese status, in agreement with our previous genome scan [1].

Mutations in the POMC gene, located in the coding region have been described in Caucasians and are responsible for rare cases of obesity with early age of onset and a recessive mode of inheritance [4]. Thus, we considered that it remained worthwhile to look for a role of putative mutations in the POMC gene as a genetic risk for common forms of obesity as well. Among 59 patients from 48 families contributing to the linkage with leptin concentrations only two previously described polymorphisms were, however, detected: a 9 bp insertion and a $7566 \mathrm{C}>\mathrm{T}$ variation in the 3'UTR [3, 7]. None of the two variants was associated with obesity, diabetes or serum leptin or lipid concentrations. Our data, in accordance with recent reports of the $P O M C$ gene mutation screening in Danish and French cohorts [7, 10], showed no association between polymorphisms in the POMC gene and obesity in Caucasian groups. Thus genetic variations in the coding sequences of the $P O M C$ gene are unlikely to be a major cause of obesity in French Caucasian obese families. Notably, the recessive mode of inheritance of monogenic obesity due to POMC mutations suggests that severe impairment of the $P O M C$ function generates an early-onset massive obese phenotype. Under a recessive model genetic polymorphisms inducing slight variations of the $P O M C$ gene function could, however, contribute to polygenic obesity. Thus in our cohort linkage results show evidence of linkage between the POMC locus and quantitative variations of obesity-related phenotypes (serum leptin concentration and z-score) rather than with the obesity status.

Although polymorphisms in the POMC gene are not associated with obesity or with obesity related phenotypes, the linkage of serum leptin concentrations with D2S2221, D2S171 and D2S2337 markers observed, if true, suggests an unknown functional variant in the 2 p21-23 region. As the regulating regions of $P O M C$ gene are still mostly not known, it is possible that a functional sequence modifying $P O M C$ expression or a nearby gene which is independent of $P O M C$ but also interacting with energy balance or both are responsible for the linkage which has been observed with obesity-associated phenotypes. Our data confirmed that the region surrounding the POMC locus is probably involved in the genetic variation of leptin concentrations and BMI in French Caucasian obese families although no mutation in the coding regions of $P O M C$ seems to contribute to this linkage. It is likely that the advancement of the Human Genome Sequencing project and the future release of DNA sequences at $2 p$ 21-23 will make it easier to search for the obesity gene that maps in this chromosomal region.

Acknowledgements. We thank our patients for participating in this study. This work was supported by a grant from Eli Lilly. 


\section{References}

1. Hager J, Dina C, Francke S et al. (1998) A genome-wide scan for human obesity genes reveals a major susceptibility locus on chromosome 10. Nat Genet 20: 304-308

2. O'Donohue TL, Dorsa DM (1982) The opiomelanotropinergic neuronal and endocrine systems. Peptides 3: 353-395

3. Hixson JE, Almasy L, Cole S et al. (1999) Normal variation in leptin levels in associated with polymorphisms in the proopiomelanocortin gene, POMC. J Clin Endocrinol Metab 84: 3187-3191

4. Krude H, Biebermann H, Luck W et al. (1998) Severe early-onset obesity, adrenal insufficiency and red hair pigmentation caused by POMC mutations in humans. Nat Genet 19: $155-157$

5. S.A.G.E: Statistical Analysis for Genetics Epidemiology, Release 2.2. (1994) Computer program package available from the Department of Biometry and Genetics, LSU Medical Center, New Orleans

6. Morris JC, Bertram CE, Lowry PJ, Savva D (1994) Cryptic trinucleotide repeat polymorphism in the POMC gene. Hum Mol Genet 3: 2080

7. Echwald SM, Sorensen TI, Andersen Tet al. (1999) Mutational analysis of the proopiomelanocortin gene in Caucasians with early onset obesity. Int J Obes Relat Metab Disord 23: 293-298

8. Comuzzie AG, Hixson JE, Almasy L et al. (1997) A major quantitative trait locus determining serum leptin levels and fat mass is located on human chromosome 2. Nat Genet 15: 273-276

9. Rotimi CN, Comuzzie AG, Lowe WL et al. (1999) The quantitative trait locus on chromosome 2 for serum leptin levels is confirmed in African-Americans. Diabetes 48: 643-644

10. Vaisse C, Clement K, Durand E et al. (2000) Melanocortin4 receptor mutations are a frequent and heterogeneous cause of morbid obesity. J Clin Invest 106: 253-262 